This journal is the official publication of Bangladesh Society of Physiologists (BSP)

Web URL: www.banglajol.info/index.php/JBSP

Abstracted /indexed in Index Copernicus, Director of Open Access Journal, Index Medicus for South East Asia Region, Google Scholar, 12OR, infobse index, Open J gate, Cite factor, Scientific indexing services

pISSN-1983-1213; e-ISSN-2219-7508

Article

Article information:
Received on $11 / 7 / 2018$
Accepted on $13 / 11 / 2018$
DOI: https://doi.org/10.3329/jbsp.v13i2.39481

Corresponding author:

Dr. Tamanna Binte Habib

Lecturer, Department of Physiology

Dhaka Medical College, Dhaka.

E-mail:tamannapompy1234@ gmail.com or

shimu109@gmail.com

Cite this article:

Habib TB, Akhter QS. The effect of fish oil

capsule on serum total cholesterol and

triglycride levels in type-2 diabetic patient

J Bangladesh Soc Physiol 2018;13(2): 73-77

This article is open access licensed under CC BY NC SA which allows readers copy, distribute, display, and perform the work and make derivative works based on it only for noncommercial purposes.

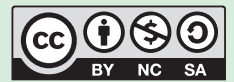

\section{The effect of fish oil capsule on serum total cholesterol and triglycride levels in type-2 diabetic patient}

\author{
Tamanna Binte Habib ${ }^{1}$, Qazi Shamima Akhter ${ }^{1}$ \\ 1. Department of Physiology, Dhaka Medical College, Dhaka.
}

\begin{abstract}
Background: Diabetes Mellitus (DM) is one of the common metabolic disorders that have effects on lipid metabolism. Fish oil supplementation may improve lipid abnormalities in diabetic patient.Objective: To observe the effect of supplementation of omega-3 fatty acid on total cholesterol (TC) and triglyceride(TG) level in type $2 \mathrm{DM}$. Methods: A prospective interventional study was conducted from January 2017 to December 2017. A total numbers of 52 diagnosed type 2 diabetic patients of both sexes were selected with age 40 to 50 years. Among them, 27 type 2 diabetic patient with supplementation of omega 3 fatty acid ( $2 \mathrm{~g} /$ day) for 12 weeks was considered as study group. Another 25 type 2 diabetic patients without supplementation of omega 3 fatty acid was considered as control group. The study subjects were selected from Outpatient Department of Endocrinology, Dhaka Medical College Hospital, Dhaka and personal contact from Dhaka city.Serum TC and TG were estimated by enzymatic endpoint method in autoanalyzer.The study parameters were measured at base line and after 12 weeks of study period in both groups. For statistical analysis, Paired Student's ' $t$ ' test and Unpaired Student's ' $t$ ' test were performed as applicable using SPSS for windows version 16.0. Results: In this study serumTC and TG levels were significantly lower $(\mathrm{p}<.001)$ in diabetic patients after supplementation with omega3 fatty acid in comparison to that of their baseline value.Again, after 12 weeks, serum TC and TG levels were significantly lower $(\mathrm{p}<.001)$ in diabetic patients after supplementation with omega-3 fatty acid in comparison to control group. In control group, serum TC and TG levels were almost similar both at baseline and after 3 months of follow-up. Conclusion: After analyzing the results of the study, it can be concluded that omega-3 fatty acid may improve serum TC and TG levels in type 2 diabetic patient and may be helpful to minimize the complications of type-2 DM.
\end{abstract}

Keywords: DM, Serum TC, Serum TG, Omega-3 fatty acid. 
Introduction

D $\mathrm{M}$ is a group of metabolic disease characterized by hyperglycemia resulting from defect in insulin secretion or insulin action or both. The chronic hyperglycemia of diabetes is associated with long term damage dysfunction and failure of various organs especially the eyes, kidneys, nerve, heart and blood vessel ${ }^{1}$.Diagnostic criteria of DM are fasting plasma glucose level $\geq 7.0 \mathrm{mmol} / 1(126 \mathrm{mg} /$ dl) or plasma glucose 2 hours after an oral glucose $\geq 11.1 \mathrm{mmol} / \mathrm{L}(200 \mathrm{mg} / \mathrm{dl})$ and $\mathrm{HbAlc} \geq$ $6.5 \%{ }^{2}$. The prevalence of T2DM is expected to rise from 285 million in 2010 to 438 million by the year of $2030^{3}$. Within 2030, the prevalence of DM will be 11.1 million in Bangladesh ${ }^{4}$.

Insulin is the potent anabolic hormone which is essential for appropriate tissue development, growth and maintenance of whole body glucose homeostasis. Insulin regulates glucose homeostasis by increasing the rate of glucose uptake into striated muscle and adipose tissue.In the skeletal muscle, insulin prompts glucose uptake by stimulating translocation of GLUT-4 to plasma membrane ${ }^{5}$. Insulin resistance occurs when the insulin sensitive tissue loses response to insulin. The basic effect of insulin resistance on glucose metabolism is to prevent the uptake and utilization of glucose by most cells of the body. As a result blood glucose concentration increases, cell utilization of glucose falls, utilization of fat increases and free fatty acid level increases in blood ${ }^{6}$.

Omega-3 Fatty acids are a group of polyunsaturated fatty acids consists of alphalinolenic acid (ALA), eicosapentaenoic acid (EPA) and docosahexanoic acid (DHA). They are found in seafood including fatty fish (e.g. salmon, tuna and trout) and shellfish (e.g. crab, mussels and oysters). The omega 3 fatty acid; increases insulin sensitivity, helps in blood clotting, promote fat digestion, improve fertility, acts as a mood elevator and helps in brain development ${ }^{7}$.

Consumption of fish oil can decreases free fatty acid level, improve insulin sensitivity as well as reduce the incidence of type $2 \mathrm{DM}^{8}$. Poly unsaturated fatty acid act directly on insulin sensitive tissues, increases number of insulin receptors thus reducing insulin resistance ${ }^{9}$. Omega-3 fatty acid facilitates the action of insulin through various metabolic pathways and improve glycemic status in type-2 DM. It also facilitates the action of insulin through suppression of hepatic lipogenesis and reduces the release of TG from liver and oxidation of fatty acids in liver, thus reduces the complications in type- $2 \mathrm{DM}^{10}$.

Omega- 3 fatty acid prevents this change by increasing peroxisome proliferator receptor gamma, increasing hepatic uptake and oxidation of free fatty acid in skeletal muscle ${ }^{11}$.Some author found significant reduction in serum TC and TG levels in diabetic patient those are supplemented with fish oil ${ }^{12}$.As lipid abnormalities are common in type 2 DM. Supplementation of fish oil may prevent lipid abnormalities and reduce complications in diabetic patients.

As thereis less published data available regarding this topic in our country. Therefore, this study has been designed about the supplementation of omega-3 fatty acid on lipid profile level in Bangladeshi type-2 DM patients. It is expected that findings of this study will be helpful for better management and its complication.

\section{Methods}

This prospective, interventional study was done from Department of Physiology, Dhaka Medical College, Dhaka from January 2017 to December 2017.The research work was carried out after obtaining ethical clearance from concerned departments, Research Review Committee and Ethical Review Committee of Dhaka medical college, Dhaka. The patients were selected from outpatient department of Endocrinology, Dhaka medical college and personal contact from Dhaka city. At the Beginning of study 60 diagnosed type2 diabetic patients were randomly selected on the basis of exclusion and inclusion criteria. There were 30 patients of control group and 30 patients of study groups recruited for completion of study, After 6 weeks of study period,3 patients were dropped out from study group and 5 patients were 
dropped out from control group. Finally, total 52 type diabetic patient of both sexes with the age ranging from 40-50 years with FBG $7.0 \mathrm{mmol} / 1$ or $126 \mathrm{mg} / \mathrm{dl}, \mathrm{HbA} 1 \mathrm{c} 6.5 \%$, serum TC $200 \mathrm{mg} / \mathrm{dl}$, serum TG $150 \mathrm{mg} / \mathrm{dl}$,BMI $£ 30 \mathrm{Kg} / \mathrm{m}^{2}$ were included in this study. Subjects with history of heart, liver, endocrine disorder, insulin therapy and pregnant women were excluded from this study. For this study, 27 diagnosed type- 2 diabetic patients with omega-3 fatty acid supplementation were selected as study group and 25 type- 2 diabetic patients without oral omega-3 fatty supplementation were selected as control group. The study group again sub-divided into presupplementation group and after 12 weeks of supplementation as post supplementation group. The control group was sub-divided as pre and post follow-up group. After selection, the nature, purpose and benefits of the study were explained to each subject and informed written consent was taken from participants. Before taking blood detailed family and medical history were taken. Anthropometric measurement of the subjects was recorded and blood pressure was measured. All the information were recorded in a data schedule. With aseptic precaution, $5 \mathrm{ml}$ of venous blood was collected from ante-cubital vein by a disposable plastic syringe from each subject after overnight fasting for biochemical tests. Serum TC and TG were estimated in enzymatic end point method by auto analyzer in department of Laboratory Medicine Dhaka Medical College Hospital, Dhaka.Omega-3 fatty acid (2gm) was supplied to study group then they were asked to intake twice daily for 12 weeks with proper instructions. Subjects were instructed not to change their diet and physical activities during the course of the study. A regular telephonic contact and periodic visit was made to participants because most of them are employee of Dhaka medical college. For statistical analysis, Paired Student's ' $t$ ' test and Unpaired Student's ' $t$ ' test were performed as applicable using SPSS for windows version 16.0. Datawere expressed as mean \pm SE. The $p$ value of $<0.05$ was accepted as level of significance.

\section{Results}

In this study no significant difference were observed in age, sex, BMI, systolic and diastolic blood pressure between study and control group (Table 1).In this study, the mean serum TC and TG levels were almost similar and there is no statistical difference were observed at the beginning of the study. In study group, the mean serum TC $(\mathrm{p}<.0 .001)$ and TG $(\mathrm{p}<.0 .001)$ levels were found significantly lower in post supplementation group, than pre-supplementation group. Again the mean serum TC $(p<.0 .001)$ and TG $(p<0.015)$ levels were found significantly lower in study group compared to control group. In control group, there was no significant difference in mean serum TC and TG between pre and post follow-up group.

Table I: General characteristics of the patients in both groups $(\mathrm{N}=52)$

\begin{tabular}{lcc}
\hline Parameters & $\begin{array}{c}\text { Study group } \\
(\mathrm{n}=27)\end{array}$ & $\begin{array}{c}\text { Control group } \\
(\mathrm{n}=25)\end{array}$ \\
\hline Age $(\text { years })^{\mathrm{a}}$ & $45.90 \pm 3.80$ & $44.92 \pm 3.75$ \\
$\begin{array}{l}\mathrm{Sex}(\%)^{\mathrm{b}} \\
\quad \text { Male }\end{array}$ & $\begin{array}{c}18(66.7 \%) \\
\text { Female }\end{array}$ & $\begin{array}{c}11(44 \%) \\
14(56 \%)\end{array}$ \\
BMI $\left(\mathrm{kg} / \mathrm{m}^{2}\right)^{\mathrm{a}}$ & $25.03 \pm 2.27$ & $25.87 \pm 1.75$ \\
$\begin{array}{l}\text { Systolic BP } \\
(\mathrm{mmHg})\end{array}$ & $119.07 \pm 7.08$ & $121.79 \pm 4.47$ \\
$\begin{array}{l}\text { Diastolic BP } \\
\text { (mmHg) }^{\mathrm{a}}\end{array}$ & $79.63 \pm 6.26$ & $80.00 \pm 0.00$ \\
$\begin{array}{l}\text { Duration of } \\
\text { disease }\end{array}$ & $5.43 \pm 1.50$ & $5.35 \pm 1.57$ \\
\hline
\end{tabular}

Results were expressed as mean \pm SD. $a=$ Unpaired Student's ' $t$ ' test was performed to compare between the groups. $b=$ Chi Square test was performed to compare male and female between the groups. The test of significance was calculated and $p$ value $<0.05$ was accepted as level of significance. $\mathrm{N}=$ total number of subjects, $\mathrm{n}=$ number of subjects in each group T2DMS=Type $2 \mathrm{DM}$ with supplementation T2DM=Type 2 DM without supplementation 
Table II: SerumTC and serum TG levels in different groups $(\mathrm{N}=52)$

\begin{tabular}{lcclll}
\hline Parameters & \multicolumn{2}{c}{ Study group $(\mathrm{n}=27)$} & & \multicolumn{2}{c}{ Control group $(\mathrm{n}=25)$} \\
\cline { 2 - 3 } & Pre-supplemenation & Post-supplementation & & Pre-follow-up & Post follow-up \\
\hline $\mathrm{TC}(\mathrm{mg} / \mathrm{dl})$ & $236.70 \pm 43.98$ & $173.00 \pm 19.82^{* *}$ & & $241.92 \pm 40.04$ & $239.96 \pm 38.39^{\# \#}$ \\
$\mathrm{TG}(\mathrm{mg} / \mathrm{dl})$ & $170.04 \pm 16.26$ & $154.81 \pm 27.08^{*}$ & & $169.28 \pm 24.92$ & $166.80 \pm 21.09^{\# \#}$ \\
\hline
\end{tabular}

Results are expressed as mean $\pm \mathrm{SD}$. $a=$ Paired student's $t$ test was performed for comparison within groups and $b=$ unpaired $t$ test was performed to compare between groups. $p$ value $<0.05$ was accepted as level of significance. $\mathrm{N}=$ total number of subjects, $\mathrm{n}=$ number of subjects in each group, $=\mathrm{TC}, \mathrm{TG}=\mathrm{TG}$ T2DMS=Type $2 \mathrm{DM}$ withsupplementation. T2DM=Type $2 \mathrm{DM}$ without supplementation. $\left({ }^{*}=\mathrm{T} 2 \mathrm{DMS}\right.$ baseline vs T2DMS after 12 weeks of supplementation; \#= T2DMS after 12 weeks vs T2DM after 12 weeks $) ;(* p<.01, * * p<.001 ; \# p<.01, \# \# p<.001)$.

\section{Discussion}

In the present study, the mean serum TC, mean TG were significantly lower in patients of T2DM after supplementation with omega-3 fatty acid in comparison to that of their baseline value. Again, after 12 weeks, mean TG levels were significantly lower in type- 2 diabetic patients supplemented with omega-3 fatty acid in comparison to that of diabetic control group without omega-3 fatty acid. Almost similar results were observed by different researchers of different countries ${ }^{13-16}$. On the contrary, there were no significant difference in lipid profile in patients after supplementation of omega-3 fatty acid in comparison to that of their baseline values and diabetic control group who were not supplemented with omega-3 fatty acid ${ }^{17}$. There were a history of less physical activity in the study subjects that might be contributed the result of those study. Literature review suggested that, when serum TG level rises, it decreases the binding of insulin with its receptor through releasing some inflammatory mediator from liver that decreases insulin receptor signaling activity.Omega-3fatty acid has a role on reducing serum TG level. Peroxisome proliferator receptorá exists in the liver which increase in number in presence of omega-3 fatty acid.Anincrease in PPAR-á leads to hepatic uptake of free fatty acid. It also increases the free consequence of free fatty acid reduction helps to decrease $\mathrm{TG}$ synthesis. Thus, omega-3 fatty acid reduces serum TG level that facilitates the binding of insulin to its receptor and improves insulin sensitivity ${ }^{18}$.Omega-3 fatty acid supplementation decreases serum cholesterol level by decreasing glycolytic and lipogenic enzymes which are necessary for cholesterol synthesis. The transcription factor Sterol Regulatory Element Binding Protein-1(SREBP-1)is a precursor of cholesterol synthesis, which play an important role in expression of lipogenic genes.Omega-3 fatty acid inhibit lipogenic genes by suppressing the SREBP-1 as a result decreases cholesterol synthesis, when serum cholesterol level decreases insulin can easily bind with its receptor and improves insulin sensitivity ${ }^{19}$.

In the present study serum-TG and TC levels decreases in patients with T2DMafter supplementation of omega-3 fatty acid in comparison to their baseline value and control group. Omega-3 fatty acid supplementation increases free fatty acid oxidation as a result serum TG level decreases and it also decreases cholesterol synthesis by suppressing SREBP-1. This facilitates the binding of insulin to its receptor and improves insulin sensitivity.

\section{Conclusions}

After analyzing the results of the study, it can be concluded that supplementation of omega-3 fatty 
acid can improve serum TC and serum TG levels in patients with type-2 DM. Therefore, omega-3 fatty acid containing food may be helpful to minimize the complications in type-2 DM.

\section{Conflict of Interest: None}

\section{Acknowledgement}

The authors are thankful to the study subjects for their active, sincere and voluntary participation.

\section{References}

1. American Diabetes Association. Diagnostic and classification of DM. Diabetes Care 2017; 40(1): S11-S24

2. World Health Organization. Definition and diagnosis of DM and intermediate hyperglycemia: Report of a WHO/IDF. Consultation. [Internet].Geneva: World Health Organization;c2011. [Cited 2017 May 18].Available from ;https;//www.idf.org.

3. Ramachandran A, Snehalata C, Shetty S, Nandita A.Trends in prevalence of diabetes in Asian countries. World J of Diabetes 2012; 3(6): 110-117.

4. Baynest HW. Classification, pathophysiology, diagnosis and management of DM. J of Diabetes Metab 2015; 6(541):1-13.

5. Pessin JF and Saltiel S.Signaling pathways in insulin action: molecular targets of insulin. The $\mathrm{J}$ of Clin invest 2000;106(2) : 155-169.

6. Delarue $\mathrm{J}$ and Magnan C. Free acids and insulin resistance. Research Gate 2014 ;10(1): 142-8.

7. National Center for Complementary and Integrative Health n.d., Omega-3 supplements in depth. [Interenet] 2017[Cited on April 23]2017. Available from: http://nccih.nih.gov//omega-3 supplements in depth/html

8. Albert BB, Derraik JGB, Brenan CM, Smith GC, Glarg ML, Smith DC, Hofman PL and Cutfield WS. Higher omega-3 index is associated with increased insulin sensitivity and more favourable metabolic profile in middle-aged overweight men. Sci Rep 2014;4(6696):1-8.

9. Laila AZ and Lanza IR. Insulin -Sensitizing effects of omega-3 fatty acids: lost in translation. Nutr 2016;8 (329) :1-24
10. Lopez AL, Ramos RV, Carrillo BE. Type 2 Diabetes, PUFAs and vitamin D: their relation to inflammation. J of Immun Res 2014; 1:1-14.

11. Flachs P, Rossmeis1 M, Kopecky J. The effect of n-3 Fatty Acids on Glucose Homeostasis and Insulin Sensitivity. Phy Res 2013; 63(1): 93-98.

12. Ellulu MS, Khazai H, Patimah I, Rahmat A .Effect of long chain omega-3 polyunsaturated fatty acids on inflammation and metabolic markers in hypertensive and/or diabetic obese adults: a randomized control trial. Food \& Nut Res 2017;60(1) :1-9.

13. Udupa A, Nahar P, Shah S, Kshirsagar, Ghongane B .A comparative study of effects of omega 3 fatty acids, alpha lipoic acid and vitamin $\mathrm{E}$ in type 2 DM. Ann Med Health Sci Res 2013;3(3):442-6.

14. Zambon S, Friday KE, Childs MT, Fujimoto WY, Bierman EL and EnsinckJ W.Effect of glyburide and ù3 fatty acid dietary supplements on glucose and lipid metabolism in patients with non-insulindependent DM. Am J of Clin Nutr 1992;56(1): 447-54.

15. Thota RN, Acharya SH, Abbott KA et al. Curcumin and long chain omega-3 polyunsaturated fatty acids for prevention of type-2 diabetes.Trials 2016; 17(565):1-11.

16. Mahmoodi MR, Kimiagar M, MehrabiY.The effect of omega-3 plus vitamin $\mathrm{E}$ and zinc plus vitamin $\mathrm{C}$ supplementation on cardiovascular risk markers in postmenopausal women with type-2 diabetes. Thera Adv Endocrinol Metab 2014; 5(4): 67-76.

17. Virtanen KJ, Mursu J, Voutilainen S,Uustupa M and Tuomainen TP.Serum Omega-3 Polyunsaturated Fatty Acids and Risk of Incident Type 2 Diabetes in Men. Diabetes Care 2014:37(1):186-96.

18. Shidfar F, Keshavaraz A, Hosseyni S, Ameri A. Effect of omega -3 fatty acid supplements on serum lipids, apo-lipopotein and malondehyde in type 2 diabetes patient. East Mediterranean Health J 2008;14(2):305-12.

19. Xu J, Nakamura MT, Cho HP, Clarke SD. Sterol regulatory element bindingprotein-1 expression is suppressed by dietary polyunsaturated fatty acids. A mechanism for the coordinate suppression of lipogenic genes by polyunsaturated fatty acids. J Biol Chem. 1999 ;274(33):23577-83. 